\title{
Social impacts as a function of place change
}

- Bob McKerchera,,

- Dan Wanga,

- Eerang Park,

doi:10.1016/j.annals.2014.11.002

\section{Highlights}

•

This paper argues that both impacts felt by and attitudes to tourism are a function of place change.

Identifies destinations as consisting of tourism, non-tourism and shared place.

Shows the relationship between place change, attitudes and life cycle stage.

Argues for a rethink of social impact research.

Identifies 9 types of place change that can affect tourism attitudes. 


\section{Abstract}

This paper argues that both impacts felt by and attitudes to tourism are a function of place change. Destinations are comprised of three types of place: tourism, non-tourism and shared. It is believed attitudes are generally positive when stasis exists among the three types, but deteriorate during periods of rapid place change. Likewise, impacts are felt when place changes, especially when non-tourism place is transformed into either shared or tourism place. This proposition is tested through a meta-analysis of more than 90 journal articles examining social impacts of tourism. Nine types of place change were identified as well as a relationship between place change and lifecycle stage.

\section{Keywords}

- Place and space;

- Sense of place;

- Lifecycle;

- Impacts;

- Destination

\section{Introduction}

More than 140 academic papers have been published examining the impacts of tourism on host communities (Nunkoo, Smith, \& Ramkissoon, 2013). Deery, Jago, and Fredline (2012, p. 65), though, note that much of this work is derivative, leading them to conclude "research into the social impacts of tourism appears to be in a state of 'arrested development,' [where] there is a sense that the advances in understanding the impacts of tourists on host communities is incremental at best, or potentially circular." The causes are twofold: much of the research is descriptive and atheoretical; and most studies 
adopt similar methods, metrics and analytic techniques (Nunkoo et al., 2013). Essentially, the literature demonstrates that attitudes are a function of impacts felt. When the impacts of tourism are seen to be beneficial, attitudes are generally positive and when impacts are perceived to be detrimental, attitudes are negative.

These conclusions raise two fundamental questions that are not answered well in the existing body of research. The first is 'what causes impacts to be perceived as positive or negative?' Impacts are not absolute. Instead they reflect emotive responses to some action. The literature does not provide a deep understanding of what causes a factual condition or event (such as increased traffic) to be perceived as negative (congestion) or positive (rejuvenation brought about by new visitors). The second question is 'why do attitudes change over time, when the underlying triggering event may not change? ' As shown in this paper, when the body of literature is examined holistically, attitudes are generally positive during the pre-development and early lifecycle stages, decline during periods of rapid growth and then return to being positive in the maturity and late maturity stages, even though the initial trigger event remains unresolved. The best explanation offered is that residents get used to these changes. But, the process of adjustment is rarely explained convincingly.

This paper proposes that the answer to both questions may be found in the concept of place and the evolving social structure of destinations brought by place change. Place is a socially constructed idea, scripted with certain rules of accepted behaviour (Crang, 2004 and Tuan, 1979) that must be adhered to in order for the occupant to feel he or she belongs. Because place is dynamic (McCabe and Stokoe, 2004 and Urry, 2001), it becomes a site of negotiation, as movements by individuals and social groups through and use of place ebb and flow (Shaw \& Williams, 2004). Since tourism is recognised as an agent of change in destinations (Deery et al., 2012), then it follows it is also be an agent of place change.

The study has three broad objectives. First, the authors argue that destinations consist of three types of dynamic place that sometimes exist in equilibrium and sometimes are subjected to sudden change. 'Tourism Place' is signalled and signposted as locations where tourists are welcome. Both tourists and locals coexist in 'Shared Place,' while 'Non-tourism Place' is designated exclusively for residents and where tourists are not welcome. Changes in the balance among the three types of place can disrupt local communities. The second objective is to determine if an association exists between 
place change and tourism impacts. The third objective is to determine if changes in attitudes across the destination lifecycle are related to place change and/or place change adjustment. Here we refer to Butler's (1980) work. These propositions are tested through a meta-analysis of 92 journal articles that examine the impacts of tourism on host communities.

\section{Place and place change}

Historically space and place have been theorized as bounded geographic entities (Tapsell \& Tunstall, 2008). However, a series of studies illustrate that while both are related, geographic space is also clearly differentiated from social place. Tuan (1975)popularized the idea of place by arguing that while space contains both physical and social dimensions, the socially constructed meaning people ascribe to space transforms it into place and gives it value. As Tuan (1975, pp. 164-165) states space "lacks content; it is broad, open, and empty...Place, by contrast, is the past and the present, stability and achievement."

The associated concept of sense of place explains the emotional tie between people and place (Mahon,

2007 and Montgomery, 1998). Sense of place has three interrelated elements: place identity, place dependence, and place attachment (Jorgensen \& Stedman, 2001). Place identity involves dimensions of self that define the individual's personal identity through a complex pattern of conscious and unconscious ideas, beliefs, preferences, feelings, values, goals and behavioural tendencies (Proshansky, 1978). Twigger-Ross and Uzzell (1996) identified four features of place identity. The first is distinctiveness, which summarizes the continuity of self and establishes that person as having a place-referent relationship with his/her home environment. The second feature, continuity, is a reflection of an individual's desire to preserve some type of connection over time, for having control over the maintenance of continuity is important for psychological well-being. The third element of self-esteem relates to feelings of worth or social value. The last element, self-efficacy, can be maintained if the environment facilitates or at least does not hinder a person's everyday lifestyle. Place identity can be threatened if any or all of these dimensions are compromised.

Place dependence is defined by Stokoe and Shumaker (1981, p. 457) as "occupant's perceived strength of association between him or herself and specific places." It is based on the functional roles places play and their ability to satisfy the 
needs of the individual. Individuals develop stronger place dependency when that place best suits their goals and weaker place dependency when it no longer satisfies their goals (Jorgensen and Stedman, 2001 and Stokoe and Shumaker, 1981).

Finally, place attachment reflects a positive bond between groups or individuals and their environment (Low \& Altman, 1992) that imbues inhabitants with a sense of belonging or meaning (Gustafson, 2006). In particular, it relates to the idea of insidedness/outsidedness. Being an "insider" is to feel safe, at home and attached, while feelings of "outsidedness" are to experience the opposite (Turner, Turner, \& Carroll, 2005). The more one feels like an insider, the more one is likely to feel a strong sense of attachment and emotional right to occupy place, and concomitantly, the more others are labelled as outsiders with no legitimate right of entry (McCabe \& Stokoe, 2004).

Neither place attachment nor entitlement to occupy place are singular or absolute, though (Turner et al., 2005). Place can have different meanings for different groups of individuals who may also have differing, but still legitimate levels of attachment (Corsane \& Bowers, 2012). It is for this reason that Shamai and Ilatov (2005) suggest sense of place exists along a continuum, whereby even temporary residents can develop a sense of place (Gustafson, 2006, Stewart et al., 1998 and Williams and McIntyre, 2012). Indeed, Gilchrist (2004) suggests that as social animals, perhaps it is imprinted on us that we must seek places where we belong, even if we are outsiders. In addition, place is actively created and recreated (Shaw \& Williams, 2004), rendering it, ultimately, as a site of negotiation. Stasis is achieved when a balance exists between and among different stakeholders, but conflict can occur when place becomes contested by different stakeholders with different value sets (McKercher, du Cros, \& Weber, 2008), especially when a perception exists that people must fight over a fixed-pie asset base, which produces winners and losers (Gramann \& Burdge, 1981).

Social disruption theory is closely related to place change. This theory states that communities experiencing rapid growth typically enter a period of generalized crisis that may lead to a wide array of social problems as changes penetrate throughout communities and at individual levels (Park \& Stokowski, 2009). Place change can include economic transformation, new class divisions and in migration of both permanent and short-term residents that lead to fundamental community restructuring (Nelson, 2001). However, social disruption is not permanent. Instead it is transitional whereby, eventually communities adapt to these changes over time (Purdue, Long, \& Kang, 1999). Quality of life may decline 
initially, will eventually stabilize and then improve as both individuals and communities, adapt for as Greider, Krannich, and Berry (1991) note, they are resilient. Parenthetically, social disruption theory also highlights one of the challenges of looking at tourism impacts, especially among emerging economies, for it is often hard to disentangle impacts tourism from impacts brought by the broader development process (Britton, 1989).

\section{Place within destinations: tourism place, non-tourism place and shared place}

The UNWTO (2002) defines a local destination as "a physical space that includes tourism products such as support services and attractions, and tourism resources. It has physical and administrative boundaries defining its management, and images and perceptions defining its market competitiveness. Local destinations incorporate various stakeholders, often including a host community, and can nest and network to form larger destinations." This definition provides insights into destination minima and maxima by excluding, at one end, resort complexes regardless of their size, and at the other end states/provinces, countries or multinational agglomerations (Lew \& McKercher, 2006). It further infers tourism activity could occur throughout a destination, when in reality, tourism is a spatially selective activity that is clustered in relatively compact precincts anchored by shopping, transport hubs, hotels and/or primary attractions (Dredge, 1999 and Tunbridge and Ashworth, 1996).

Building on these observations, destinations can be conceived of as comprising three types of place. 'Tourism place' is designated for the primary use of tourists. 'Non-tourism place' is designated exclusively for local residents. 'Shared place' is used by both residents and tourists use. The proportion of tourism, non-tourism and shared place is defined by the volume of tourists, the configuration of the destination and the stage of development of the tourism industry. Each type of place has its own rules of accepted behaviour, in accordance with Crang's (2004) earlier assertion and, building on semiotic theory (Echtner, 1999 and Williams et al., 1992), each is also clearly signposted by a variety of markers that signal its identity and legitimacy of use by certain groups.

Tourism place is something that is either constructed or signified for and by tourists as a medium through which the tourist experience is negotiated (Crouch, Aronsson, \& Wahlstrom, 2001). Since tourists exist outside a community's normal social space, they look for signs and symbols of insidedness where they are welcomed. Berger (2008)notes tourists may not 
realize they are engaged in semiotic activity, but they function as semioticians, none-the-less, looking for cues that signify belongingness. Hayllar, Griffin, and Edwards (2008) observe creating a distinctive sense of place is fundamental to the tourist experience, even though it could be derived from different attributes in each tourism precinct. Tourism places are identified in brochures, tourist maps and promoted by destination management organisations, while a variety of visual and non-visual markers, including the presence of other tourists, provide cues that these places are suitable for them.

In most cases, though, most of a destination is comprised of non-tourism place. Non-tourism place represents areas where local residents live, work, shop and go about their daily routines. They develop a deep bond through their family, occupations, daily lives, and their social activities (Kianicka, Buchecker, Hunziker, \& Müller-Böker, 2006). Non-tourism place is thus signalled and signposted as places for locals, and concurrently, unambiguously signalled as places that are either not relevant to tourists, or where tourists are not welcomed. From a touristic perspective, non-tourism place essentially represents a void to be transited through to reach other tourism or shared space.

Shared place is hybrid place suitable for both tourists and locals. Though Hayllar et al. (2008) did not use this term explicitly, they described the idea of shared place as being part of the everyday fabric of the destination such as transport hubs, shopping and dining districts. Here, both are welcome and both use the same place to achieve similar goals.Snepenger, Murphy, O'Connell, and Gregg (2003), for example have written about how tourists and locals use and share the same shopping space. Much of the downtown core of urban destinations, as well as trendy shopping and dining districts reflect shared place.

Normally, as with most other systems, the relationship between these three types of place evolves toward some form of equilibrium, or coexistence, where each is well defined and both locals and tourists respect their boundaries. But as Russell and Faulkner (1999) note, many systems which normally exhibit steady-state characteristics are periodically disturbed by changes which precipitate a period of turbulence until a new steady-state is established. Stasis is, therefore, most likely to be observed during the early stages of a destination's lifecycle where little tourism space exists, or in the maturity stage where the three types of place are clearly delineated and a new balance has been achieved. On the other hand, place change is most likely to occur during periods of rapid growth when non-tourism place is transformed into shared or tourism place. 


\section{Method}

A meta-analysis of journal articles analyzing community attitudes to tourism was undertaken to answer the research questions. More than 160 prospective papers was identified from works by Easterling (2004) and Deery et al. (2012), and supplemented by a Google Scholar and Scopus search. Each paper was then read by at least two authors to determine if it met criteria for inclusion. To be included in the study, papers had to be empirical, identify the lifecycle stage of the study area, specify a generalized community attitude to tourism and also identify key factors that influenced attitudes in order to be considered. Examples of the types of paper that did not meet these criteria, include some important conceptual papers (e.g. Ap, 1992, Butler, 1980 and Doxey, 1975), papers that highlight instrument development (e.g., Ap \& Crompton, 1998) and much work using Structural Equation Modeling.

Ultimately, 92 journal articles were included in this study. Each paper was then re-read by at least two authors and the core information entered onto an Excel spreadsheet. This spreadsheet contained such details as author, year, location, lifecycle stage, overall attitude to tourism, the types of impacts noted, factors that moderated or modified impacts, and the like. In addition, key passages were copied. This information was then transferred to an SPSS spreadsheet, where the original qualitative information was transformed into a quantitative format for ease of analysis. Content analysis was used to code impacts into 20 positive and 53 negative types. A two-step iterative process was then undertaken to reduce this set to nine broad place change thematic domains and 37 sub-themes within these domains (28 negative and nine positive).

The determination of the community attitude to tourism was based on the dominant view expressed by the majority of respondents each paper. The authors acknowledge that many of the papers identified varying attitudes across the population and that attitudes to tourism can be influenced by a wide array of moderating factors. Williams and Lawson (2001) present an excellent summary of the literature on intervening factors including: distance from tourism activity, intensity of tourism activity, length of residency, personal economic reliance on tourism, ethnicity, retail activity attributable to tourism, destination life cycle stage, level of knowledge about tourism, level of contact with tourists, impact on local recreation opportunities, gender, and perceived ability to influence planning decisions. 
The limitations of using secondary data and meta analysis must be recognized. Secondary data is a valid method providing the survey instrument and resultant data satisfy reliability, sensitivity, fitness and validity criteria for the desired purpose (Saunders, Lewis, \& Thornhill, 2000). Reliability and sensitivity criteria relate to the extent to which data can provide consistent results and fine enough detail for the purpose of the research. Fitness recognizes that data collected for one purpose may not be relevant, timely or suitable for another purpose. Validity refers to the degree to which the instrument can predict a criterion (Pizam, 1994). In this case, reliability is assured as the papers included used similar methods and metrics to assess attitude and impacts. Sensitivity was also considered when selecting papers, for candidate papers needed to state explicit results for individual variables. It is for this reason that papers using Structural Equation Modeling were excluded, unless the authors also included descriptive statistics. Papers satisfied the fitness criteria if they specified a lifecycle stage and overall attitude to tourism, along with documenting impacts. Finally, collectively, the papers enabled the research questions to be answered.

Meta analysis aggregates research findings from a number of empirical studies. Gretzel and Kennedy-Eden (2012) note the method has potential to offer new insights into a collective body of research, but also runs the risk of bias by comparing things that are not comparable. In particular, original meanings and the contextual information are often ignored if researchers focus only on results. As such, they caution that clear criteria for inclusion and exclusion must be defined to ensure like with like comparisons, or alternately to control for contextual differences, as much as possible. Effective meta analysis studies begin with a clear definition of the research question and research hypotheses or propositions. Studies are then included based on the criteria determined by the research questions. This study began with the establishment of clear inclusion criteria, and while the authors recognize fully that each case is context specific, the methods and metrics used are also sufficiently similar to facilitate meta analysis at an aggregated level.

\section{Findings}

The findings section is divided into two parts. The first part tests whether observed impacts can be attributed to place change. The second part evaluates the relationship between overall attitude to tourism, place change and destination lifecycle stage. 


\section{Impacts as a function of place change}

Reinterpreting impacts as a function of place change led to the identification of nine major place change thematic domains. The findings suggest that 'place' within a touristic sense has multiple social, spatial and economic connotations. Some forms of place change affect individuals directly (personal lifestyle, congestion, dislocation), others were felt indirectly at a community level (generic community, economic, structural), while some represented a hybrid of both (inflation, resource, amenity). Table 1 lists each type, identifies impact sub-themes associated with each domain and indicates the number of instances where positive or negative cases were noted. In total, almost 290 different incidences of place change were identified, including just under 200 cases of negative place change and slightly more than 90 cases of positive change.

Table 1.

Evidence of Place Change.

\begin{tabular}{|c|c|c|c|c|c|c|c|c|c|c|}
\hline & $\begin{array}{l}\text { Generic } \\
\text { communit } \\
y\end{array}$ & $\begin{array}{l}\text { Personal } \\
\text { lifestyle }\end{array}$ & $\begin{array}{l}\text { Congestio } \\
\mathrm{n}\end{array}$ & Dislocation & $\begin{array}{l}\text { Cost of } \\
\text { living }\end{array}$ & Economic & Resource & Amenity & Structural & $\begin{array}{l}\text { Total } \\
\text { mention } \\
\mathrm{s}\end{array}$ \\
\hline $\begin{array}{l}\text { Positive } \\
\text { place } \\
\text { change }\end{array}$ & 34 & & & & & 45 & & 13 & & 92 \\
\hline $\begin{array}{l}\text { Negative } \\
\text { place } \\
\text { change }\end{array}$ & 40 & 16 & 38 & 17 & 21 & 24 & 18 & 6 & 15 & 195 \\
\hline $\begin{array}{l}\text { Indicator } \\
\mathrm{s}\end{array}$ & $\begin{array}{l}\text { Negative: } \\
\text { loss of } \\
\text { traditional } \\
\text { lifestyles; } \\
\text { rapid } \\
\text { cultural } \\
\text { change; } \\
\text { communit } \\
\text { y } \\
\text { character; } \\
\text { moral } \\
\text { decay; } \\
\text { family }\end{array}$ & $\begin{array}{l}\text { Negative: } \\
\text { sense of } \\
\text { invasion; } \\
\text { need to } \\
\text { curtail } \\
\text { activities; } \\
\text { turn locals } \\
\text { into } \\
\text { attractions } \\
\text {; tourism } \\
\text { imposed } \\
\text { on lifestyle }\end{array}$ & $\begin{array}{l}\text { Negative: } \\
\text { traffic; } \\
\text { shortage } \\
\text { of parking } \\
\text { spaces; } \\
\text { crowding } \\
\text { at public } \\
\text { places }\end{array}$ & $\begin{array}{l}\text { Negative: } \\
\text { Physical } \\
\text { displacemen } \\
\mathrm{t}\end{array}$ & $\begin{array}{l}\text { Negative } \\
\text { : } \\
\text { Inflation; } \\
\text { higher } \\
\text { costs of } \\
\text { living; } \\
\text { higher } \\
\text { housing } \\
\text { costs }\end{array}$ & $\begin{array}{l}\text { Negative: } \\
\text { loss of } \\
\text { shops; low } \\
\text { paying } \\
\text { jobs; job } \\
\text { loss; } \\
\text { economic } \\
\text { dependenc } \\
\text { y on } \\
\text { tourism } \\
\text { Positive: } \\
\text { more jobs; } \\
\text { higher }\end{array}$ & $\begin{array}{l}\text { Negative: } \\
\text { increased } \\
\text { competitio } \\
\text { n for } \\
\text { natural and } \\
\text { recreationa } \\
\text { I } \\
\text { resources; } \\
\text { land } \\
\text { disputes; } \\
\text { urban } \\
\text { sprawl }\end{array}$ & $\begin{array}{l}\text { Negative: } \\
\text { loss of } \\
\text { recreational } \\
\text { diversity } \\
\text { Positive: } \\
\text { more leisure } \\
\text { and } \\
\text { recreational } \\
\text { opportunities } \\
\text {; better } \\
\text { public } \\
\text { transport } \\
\text { and other }\end{array}$ & $\begin{array}{l}\text { Negative: } \\
\text { unstable } \\
\text { residential } \\
\text { patterns; } \\
\text { influx of new } \\
\text { residents; } \\
\text { changing } \\
\text { demographi } \\
\text { c profile; } \\
\text { second } \\
\text { home } \\
\text { developmen } \\
\text { t }\end{array}$ & \\
\hline
\end{tabular}


Generic

$\begin{array}{llll}\begin{array}{l}\text { Personal } \\ \text { lifestyle }\end{array} & \begin{array}{l}\text { Congestio } \\ \mathrm{n}\end{array} & \begin{array}{l}\text { Cost of } \\ \text { living }\end{array}\end{array}$

Economic

standard of

living;

reinvigorate

Positive:

Improved

quality of

life;

stronger

ethnic

identity;

cultural

exchange local

economy
Total

mention

$\mathrm{s}$

In each case, observed impacts can be seen as representing a change in perceptions of place identity, place dependence or place attachment. Positive impacts are noted usually through the creation of shared place. Here residents expressed an enhanced feeling of connectivity and insidedness, directly or vicariously from tourism. Negative impacts, on the other hand are associated with diminished place attachment, loss of distinctiveness, continuity, self-esteem or self-efficacy, that eventually make residents feel more like outsiders in their own community. Negative place change represents instances where transformation of non-tourism place into either shared or exclusive tourism place was seen to be detrimental to local residents, or alternately, when the creation of shared place did not live up to expectations.

Most beneficial impacts of tourism relate to the creation of shared space that enhances or is anticipated to enhance the community's overall quality of life, and in doing so to deepen residents' place attachment. Interestingly, positive place change is usually identified as an indirect community benefit, rather than providing a direct benefit to individual respondents. Beneficial economic place change was noted most frequently, with a number of studies commenting on how tourism creates jobs and reinvigorates communities in decline (Andereck and Vogt, 2000, Cooke, 1982, $\underline{\text { Reed, }}$ 1997, Vargas-Sánchez et al., 2009 and Yen and Kerstetter, 2009). Tourism is also seen to enhance place identity and place attachment by encouraging cultural exchange and better cross cultural understanding (Brida et al., 2011, Diedrich and Garcia-Buades, 2009, King et al., 1993, Liu and Var, 1986, Woosnam et al., 2009 and Yen and Kerstetter, 2009), 
strengthening local ethnic identities (Evans, 1976 and Stephenson and Ali-Knight, 2010), conserving heritage buildings (Aref, 2011) and improving the overall appearance of the communities (Allen, Hafer, Long, \& Perdue, 1993). Amenity place change results in the establishment of enhanced leisure, recreation and shopping opportunities (Byrd et al.,

$\underline{2009}$ and Perez and Nadal, 2005), provides an incentive to expand public services (Wang \& Pfister, 2008) or acts to attract an expanded market base for existing businesses (Prentice, 1993).

Negative place change falls into two broad categories. On the one hand, the creation of shared place may be seen to affect the community as a whole, rather than individual residents specifically, by diminishing place identify and place attachment or by reducing the sense of distinctiveness, continuity and self-esteem. On the other hand, both the creation of shared and exclusive tourism place may exert direct impacts on individuals through loss of self-efficacy, diminished perception of place dependence and increased feelings of being an outsider.

Indirect impacts can include a loss of continuity through the disruption of people's lives. These types of impacts were noted by Greenwood (1972) more than 40 years ago, and continue to be a common theme to the present ( $\underline{\text { Green, 2005, Tatoglu }}$ et al., 2002 and Tosun, 2002). Others note how place change results in loss of distinctiveness.Carmichael

(2000) and Gilbert and Clark (1997) comment on how tourism has damaged the historic value of towns making them less desirable places to live, while Mordue (2001) notes it has led to the falsification of local culture. Place change can affect the social structure of community by disrupting family relationships (Lepp, 2007 and Yim, 2012), turning social relationships into commercial ones (Teo, 1994), or through the moral decay of communities from perceptions of increased crime,

prostitution, drunkenness and drug use (Diedrich and Garcia-Buades, 2009, Freitag, 1994, 너su, 2000, Lankford, 1994, Liu et al., 1987, Nunkoo and Ramkissoon, 2010, Park and Stokowski, 2009 and Snaith and Haley, 1999). In particular, the inmigration of new residents can change a community's demographic and social structure, diminishing the original residents' sense of place dependence (Allen et al., 1988, Brunt and Courtney, 1999, Diedrich and Garcia-Buades, 2009, Easterling, 2005, Green, 2005, Park and Stokowski, 2009, Perez and Nadal, 2005, Tomljenovic and Faulkner, 2000 and Tooman,

1997). The net result is exacerbated social divisions within communities (Weaver \& Lawton, 2001).

Alternately, the failure of shared place to achieve desired outcomes along with unexpected consequences of shared place creation can result in alienation and loss of self-efficacy. For example, a number of studies have noted tourism jobs are low 
paying and seasonal (Davis and Morais, 2004, Hsu, 2000, Johnson and Snepenger, 1994, Lankford, 1994, Teo, 1994, Teye et al., 2002 and Tyrrell and Spaulding, 1984), produce uneven employment opportunities (La Flamme, 1979 and Yim, 2012) and broaden the gap between rich and poor (Stonich, 1998). In extreme cases tourism can result in net job loss (Tsartas, 1992). It can also adversely affect cost of living, which affects maintenance of lifestyles (Andriotis, 2005, Haralambopoulos and Pizam, 1996, Jago et al., 2006, Keogh, 1990, Korça, 1998, Pizam, 1978, Ryan and Montgomery, 1994, Stonich, 1998,Tatoglu et al., 2002 and Tovar and Lockwood, 2008) and cause house prices to rise (Cooke, 1982, Davis and Morais, 2004, Prentice, 1993, Ross, 1992, Ryan et al., 1998, Tooman, 1997 and aㅏ et al., 1985). In addition, tourists have been identified as voracious consumers who outcompete locals, creating shortages of everyday necessities (Freitag, 1994, Hudman, 1978 and Stonich, 1998) and diminishing both shopping and recreational

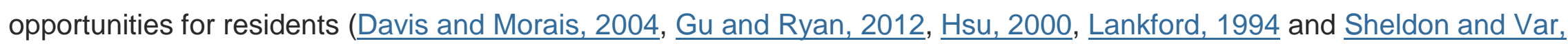
1984).

Direct impacts affect individuals personally. Personal lifestyle place change, as a form of shared place change, results in the loss of self-efficacy and a diminished sense of insidedness. A number of studies used the term 'invade' or 'invasion' to describe the level of disruption to residents personal place and daily lifestyles (Akis et al., 1996, Brougham and Butler, 1981, Connell, 2005 and La Flamme, 1979), forcing them to alter their own lifestyles and change their daily routines to avoid tourists (La Flamme, 1979; Soontayatron, 2014). Intrusion can be so invasive that Freitag (1994, p. 545) commented "for the local population, everyday routine becomes enshrouded by the ubiquitous presence of the tourists." Mordue (2001) writes about the extreme situation where residents of Port Louise, Mauritius have even changed the way they use the internal space of their homes to avoid the intrusion of tourists.

Congestion place change reflects competition for scarce resources as the result of the creation of shared place. It is typified by complaints about traffic congestion (Brunt and Courtney, 1999, Carmichael, 2000, Green, 2005, Perez and Nadal, 2005 and Weaver and Lawton, 2001, and others) and/or lack of parking facilities (Carmichael, 2000, Tomljenovic and Faulkner, 2000 and Tovar and Lockwood, 2008), as well as crowding at public spots (Easterling, 2005 and Tatoglu et al., 2002). Here, locals have lost their sense of entitlement and status as exclusive insiders and must now share place with

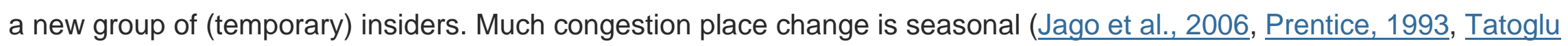


et al., 2002 and Tyrrell and Spaulding, 1984) or cyclical (Brida et al., 2011), allowing residents to revert to their normal patterns in off peak periods.

Resource place change is a function of the creation, or perceived creation of exclusive tourism place. Here residents feel their recreational needs have been traded off to satisfy those of the new tourist market (Cooke, 1982, Jurowksi et al., 1997 and Stynes and Stewart, 1993). Land disputes reflect another form of resource place change, especially when residents feel local governments accede to the demands developers (Keogh, 1990 and Yim, 2012). Unrestrained tourism development and a lack of proper planning can result in urban sprawl (Andereck and Nyaupane, 2011 and Andriotis, 2005) and the encroachment of suburban development onto the urban-rural fringe (Weaver \& Lawton, 2001), further pushing people away. The net result is the redefinition of residents as outsiders. In extreme cases, the creation of exclusive tourism place can lead the physical dislocation of locals. Examples include closing access to beach areas, which deny fishermen the opportunity to work (Ahmed, 1986, Green, 2005, Hernandez and Cohen, 1996 and Soontayatron, 2014), displacing farmers for hotel development (Greenwood, 1972 and Tooman, 1997) or exerting significant pressure on local residents to move so tourism projects could proceed (Wall, 1996). It can also occur more insidiously as the result of broader gentrification process (Gu and Ryan, 2012 and Stephenson and Ali-Knight, 2010), or by changes in the market composition resulting in retail shop keepers being forced out as businesses cater to a more affluent tourist market with different needs (Gilbert and Clark, 1997 and Gu and Ryan, 2012).

\section{Place change, attitude change and destination lifecycle}

Perceived impacts of tourism, then, can be argued to be a function of different types of place change. As discussed previously, social disruption theory suggests communities experiencing rapid growth typically enter a period of generalized crisis, but that over time communities adapt to place change. If so, changes in both the frequency and type of place change should be evident throughout a destination's life cycle, and should relate to changes in overall attitudes to tourism. To test these propositions, each of the papers was grouped into one of six lifecycle stages as defined by the authors of each paper including: pre development (nine papers), incipient or early development (18), strong or rapid growth (18), late growth or early maturity (nine), maturity (32), and late maturity or decline (six). Attitudes to tourism were also grouped into 
one of five categories: positive (35 papers), mixed but generally positive (19), neutral (23), mixed but generally negative (eight), and negative (six). The 'mixed but positive' and 'mixed but negative' groups reflect one of two situations. Either, both benefits and costs of tourism were recognized, but on balance residents felt one outweighed the other, or the sample population was segmented according to their attitude to tourism, with a majority of respondents expressing net positive or negative views. The 'neutral' includes papers where both positive and negative impacts were noted, but no strong overall opinion was voiced.

Fig. 1 shows the relationship between attitudes and the mean number of types negative or positive place changes per paper throughout a destination's life cycle. Attitudes are positive in the pre-development stage, deteriorate during the rapid growth stage and then recover as the destination enters the maturity phases of its lifecycle. The number of perceived positive place changes follows a similar pattern, peaking in the early stages of the lifecycle in anticipation of the benefits brought by tourism, troughing during the rapid growth stage, when some benefits may not have materialized and then recovering in the maturity stage. Here, tourism has become entrenched as part of the social and economic fabric of the community (Akis et al., 1996, Brunt and Courtney, 1999, Gu and Ryan, 2012, Horn and Simmons, 2002, Liu et al., 1987 and Látková and Vogt, 2011). A somewhat different situation exists when negative place change is considered. The frequency of negative place change increases dramatically during the rapid growth stage, but then plateaus, before declining only marginally in the late maturity/decline stage. This latter finding suggests that even though overall attitudes improve, some of the adverse consequences of tourism have not been resolved. Instead, residents have adjusted. 


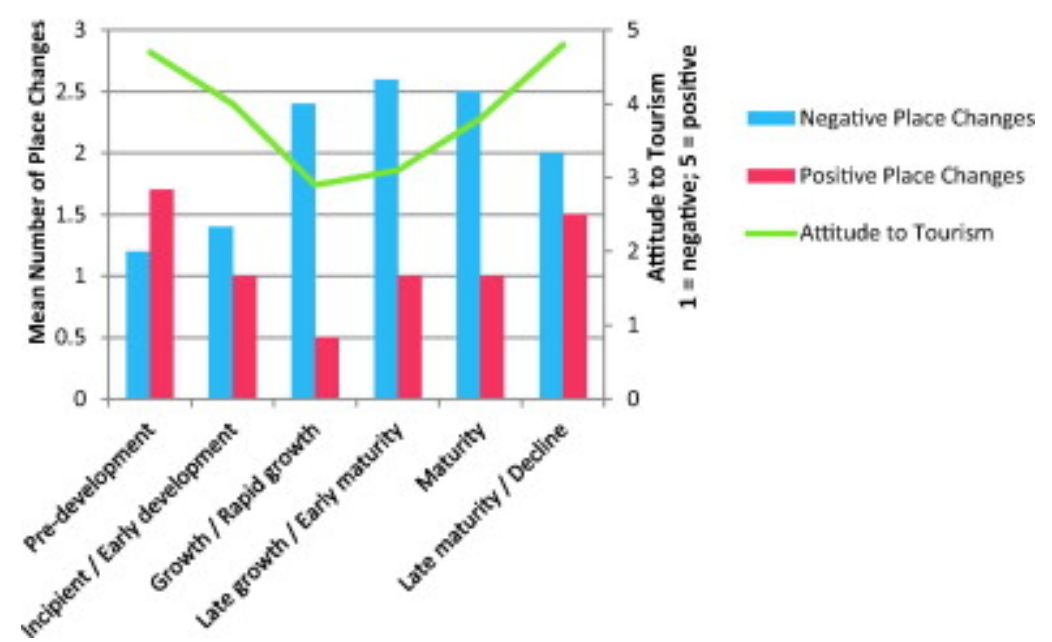

Fig. 1.

Relationship between Lifecycle Stage, Attitude to Tourism and Place Change.

Fig. 2, Fig. 3 and Fig. 4 show changes in the frequency of each of the specific types of place change identified over the destination's lifecycle. Positive place changes are shown in Fig. 2. No surprises are evident here, as the pattern for discrete types of beneficial place change mirrors that shown previously. Differences are noted when negative place change is mapped, as shown in Fig. 3 and Fig. 4. In both cases, incidents are generally low during the prodromal and early development stages, but increase sharply during the rapid growth phase. However, after this point a divergence of views is noted. On the one hand, negative generic, resource, economic and personal place change seem to be resolved as the destination matures (Fig. 3), while on the other hand, inflation, structural, amenity and congestion place change persist, and indeed increase throughout the lifecycle (Fig. 4). 


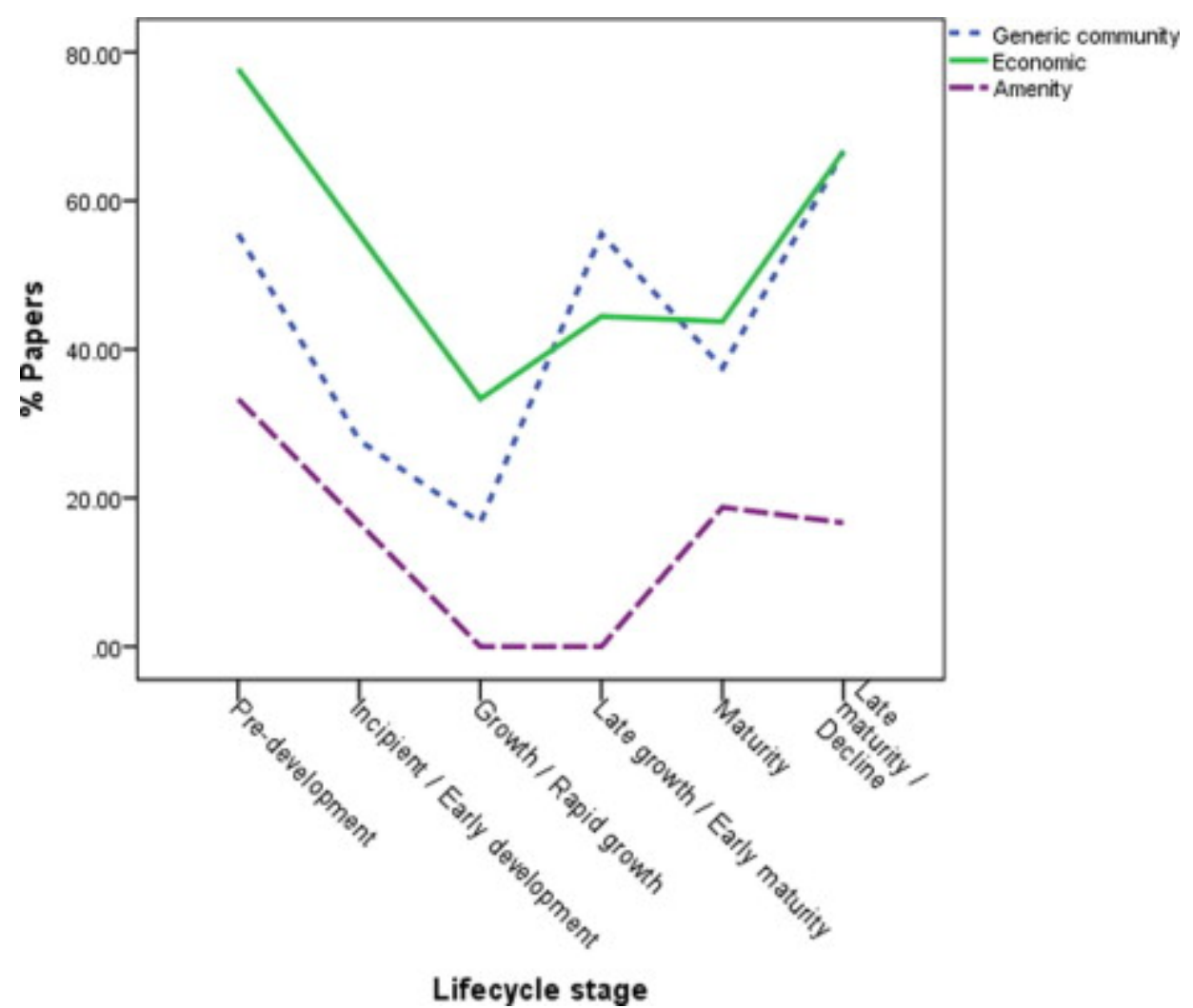

Fig. 2.

Positive Place Change by Lifecycle Stage. 


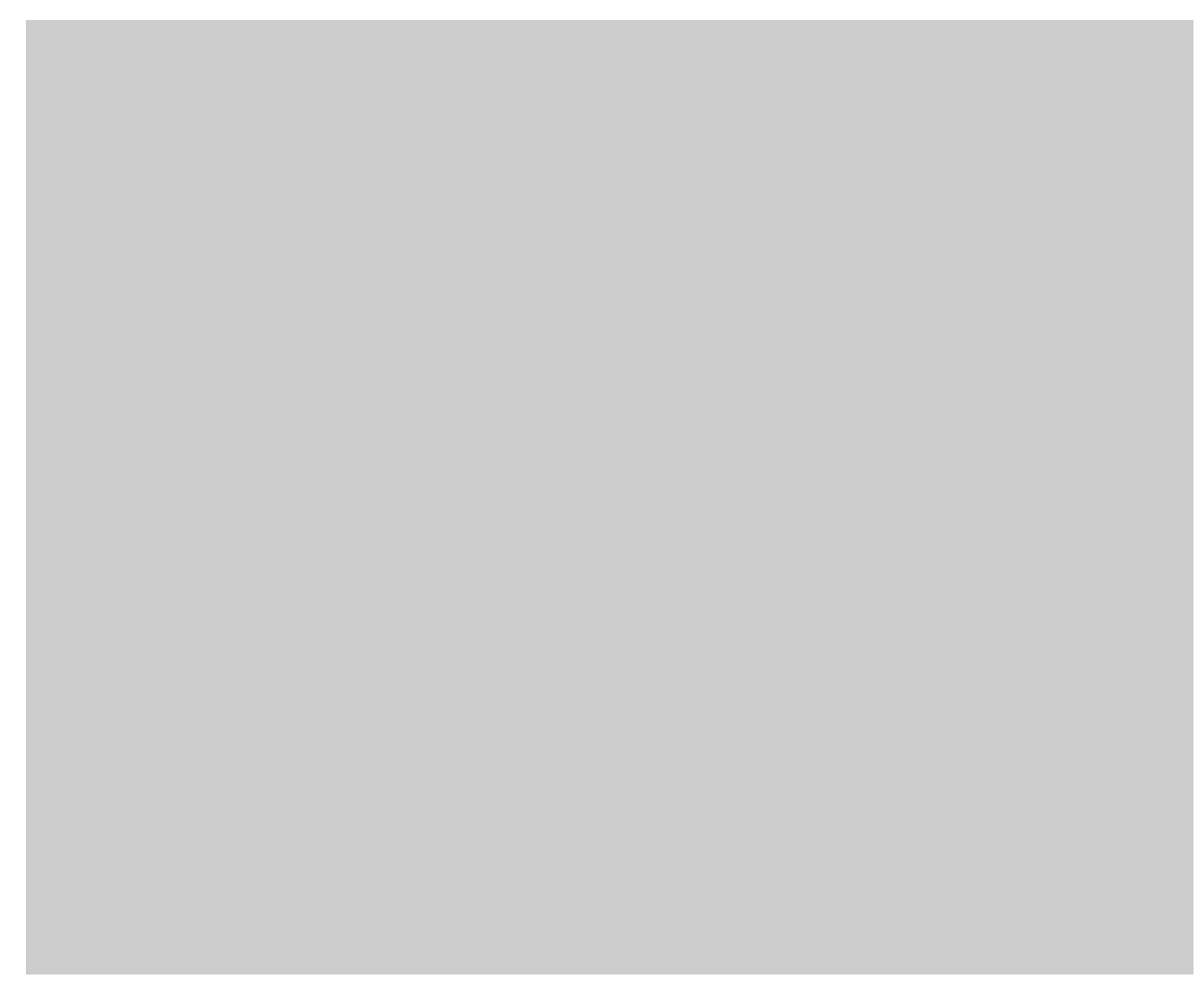

Fig. 3.

Resolved Negative Place Change by Lifecycle Stage. 


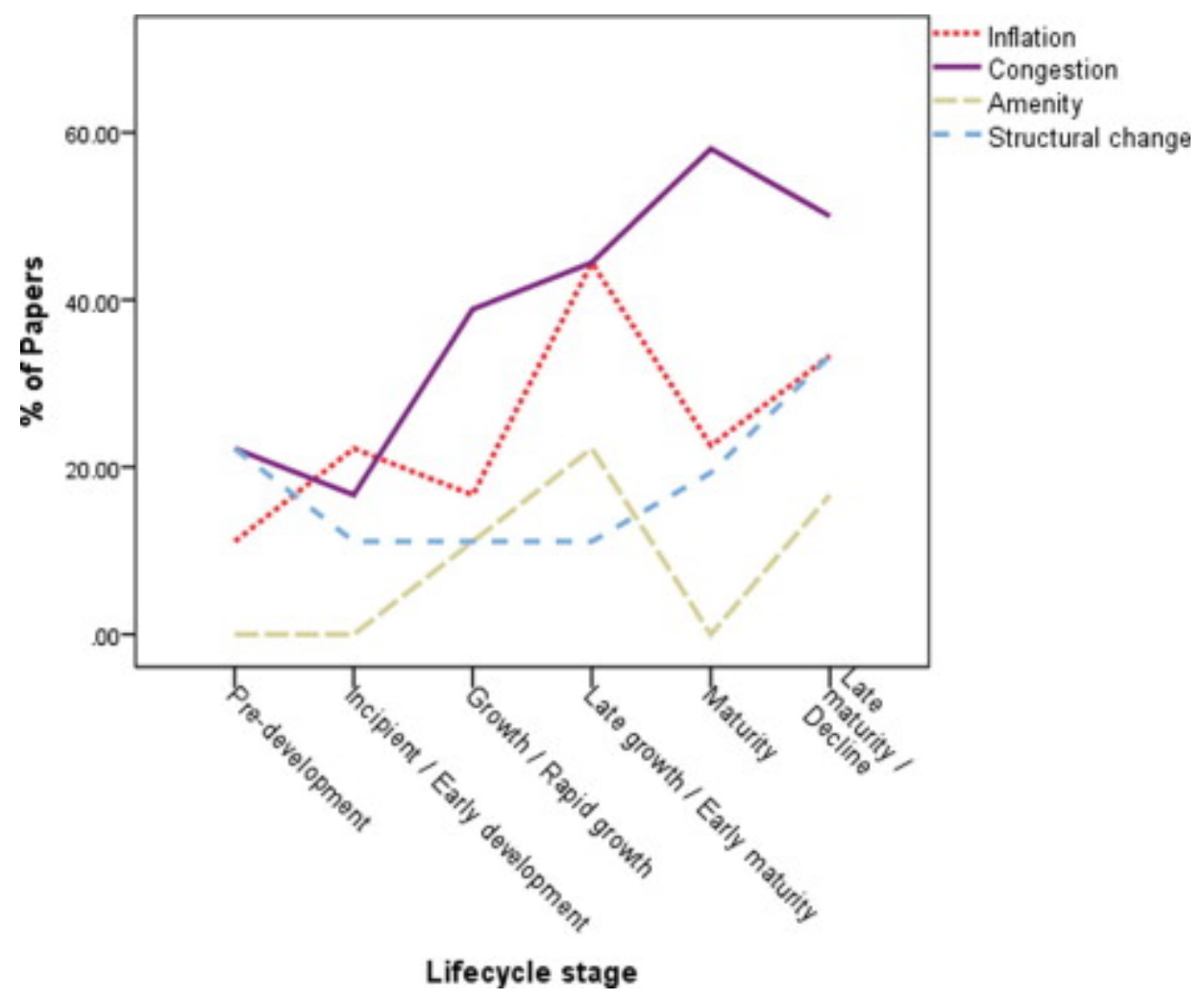

Fig. 4.

Persistent Negative Place Change by Lifecycle Stage.

These findings offer insights about both the nature of place change and how residents adjust to it. The patterns shown in Fig. 2 and Fig. 3 show a strong relationship between attitudes and perceptions of positive (direct) and negative (inverse) place change, whileFig. 4 defies this trend. In the early stages of development, tourism, perhaps somewhat naively, is seen to bring many benefits, with few costs. These changes occur at a more generic, community-wide level, with few people anticipating place change may affect them directly. As such, attitudes are generally positive. But, attitudes deteriorate during the rapid development phase, as residents are faced with the realities that the anticipated benefits of 
place change come with a number of costs and/or codicils. They may feel (or be) excluded from areas that have been transformed into exclusive tourism place or they may feel a loss of attachment, self-efficacy and diminished sense of place as they have to negotiate contested shared space with a new user group. Here, the community enters a period of forced transition that occurs faster than it can adjust. However, most of these issues are resolved in some way or another during the latter stages of development, as a new period of equilibrium returns. The social geography of the destination has been transformed, with the acceptance that new shared and exclusive tourism place has emerged.

A few patterns are notable. The incidence of personal space change diminishes rapidly during the early development and late maturity stages of the lifecycle, while displacement is noted most prominently in the maturity stage. A degree of adjustment occurs, where residents accept tourism and adjust their lifestyles to achieve a new behavioral norm, sometimes by modifying their own spatial and temporal behaviors to avoid crowds or sometimes by engaging deeply with the new types of place. For example, Snepenger et al. (2003) conducted a study of how residents and tourists use shared shopping space. They observed many differences in how 'heavy' and 'light' local users of a downtown core behaved. The more affluent heavy users saw tourism as being an important part of the local economy and appreciated the added shopping opportunities created by an influx of similarly affluent tourists. But, they did show a tendency to avoid the downtown core at certain times because of congestion brought about by tourism. The less affluent, light user, though avoided the downtown core, feeling it had changed to become a place that served the needs of tourists and the wealthy and no longer served their needs.

Changes noted in congestion, structural and to a lesser extent inflation place, reflect ongoing issues caused by the transformation of non-tourism into shared place that are not resolved over time. While residents may have adjusted their personal space to cope with tourism, they are none the less reminded of the adverse consequences of tourism when they drive through their home community, observe the structural changes that have occurred and must cope with higher prices. However, on balance, while annoying these types of place change seem to be accepted as part of the price of remaining in a tourism destination and may be balanced off by beneficial community and economic place changes associated with tourism. 


\section{Discussion and conclusion}

The study argues that destinations consist of different types of place and that an association exists between place change and both observed impacts of and attitudes to tourism. Each of the three types strives to exist in equilibrium, but is occasionally subjected to shocks. The identification of nine thematic domains of place change suggests that the concepts of place change and place attachment are complex, nuanced and have multiple social, economic connotations.

The observation that the social geography of destinations is comprised of different types of place, combined with the identification of multiple realms of place change explains why impacts are felt and attitudes to tourism change. Place and sense of place are central to the human condition. People want and need to feel attached, that they belong to places, and consequently look for signs that validate that sense of belonging. Importantly, it seems to be part of the human condition to classify peoples as insiders or outsiders. While insidedness exists along a continuum, and while people are adaptable, change occurs faster than people can adjust during periods of rapid growth, leading to a sense of alienation. Tourists are welcomed in tourism place, and accepted or tolerated in shared place. But they have no legitimate right to occupy nontourism place. The types of adverse impacts identified by the nine thematic place domains reflect the social reorientation that occurs in a destination, and also help explain how antipathy emerges when non-tourism place is transformed into shared or tourism place or where shared place becomes exclusive tourism place. Conversely, the types of positive impacts noted reflect result from the transition of tourism place to either shared or occasionally non-tourism place.

The study suggests that place within a touristic context is a multifaceted concept that exists at both a personal and community level. Moreover, place change can affect individuals directly, indirectly and ideologically. The study further suggests a typology of place change may exist. This issue has received little attention in the tourism literature, though, indicating the need for primary research to develop the idea further.

In addition, the association between attitude, lifecycle and place change is complicated and nuanced. Perceptions of positive place change follow a U-shaped curve and correspond closely to changing attitudes to tourism. However, perceptions of specific negative place change intensify through to the rapid development stage of a destination's lifecycle, but after that diverge. Some place changes are apparently resolved, while others persist. Yet in spite of their persistence 
attitudes to tourism improve over time, suggesting the ability of residents to adjust and create a new equilibrium between and among the three types of place. While the authors posit that place change is linked directly to impacts and attitudes, causality cannot be determined in this type of research. Intuitively, it seems that a causal relationship is likely. However, primary research is required to resolve the proposition explicitly.

\section{References}

1.

o Ahmed, 1986

o S. Ahmed

o Understanding residents' reaction to tourism marketing strategies

o Journal of Travel Research, 25 (2) (1986), pp. 13-18

2.

o $\quad$ Akis et al., 1996

o S. Akis, N. Peristianis, J. Warner

o Residents' attitudes to tourism development: The case of Cyprus

o Tourism Management, 17 (7) (1996), pp. 481-494

3.

o $\quad$ Allen et al., 1993

o L.R. Allen, H.R. Hafer, P.T. Long, R.R. Perdue

o Rural residents' attitudes toward recreation and tourism development

o Journal of Travel Research, 31 (4) (1993), pp. 27-33

4

o $\quad$ Allen et al., 1988 
o L.R. Allen, P.T. Long, R.R. Perdue, S. Kieselbach

o The impact of tourism development on residents' perceptions of community life

o Journal of Travel Research, 27 (1) (1988), pp. 16-21

5.

o $\quad$ Andereck and Nyaupane, 2011

o K.L. Andereck, G.P. Nyaupane

0 Exploring the nature of tourism and quality of life perceptions among residents

o Journal of Travel Research, 50 (3) (2011), pp. 248-260

6.

o $\quad$ Andereck and Vogt, 2000

o K.L. Andereck, C.A. Vogt

o The relationship between residents' attitudes toward tourism and tourism development options

o Journal of Travel Research, 39 (1) (2000), pp. 27-36

7.

o Andriotis, 2005

o K. Andriotis

o Community groups' perceptions of and preferences for tourism development: Evidence from Crete

o Journal of Hospitality and Tourism Research, 29 (1) (2005), pp. 67-90

8.

o Ap, 1992

o J. Ap

o Residents' perceptions on tourism impacts 
o Annals of Tourism Research, 19 (4) (1992), pp. 665-690

9.

- Ap and Crompton, 1998

o J. Ap, J.L. Crompton

o Developing and testing a tourism impact scale

o Journal of Travel Research, 37 (2) (1998), pp. 120-130

10.

o Aref, 2011

o F. Aref

o Residents' attitudes towards tourism impacts: A case study of Shiraz, Iran

o Life Science Journal, 8 (2) (2011), pp. 26-30

11.

o Berger, 2008

o A. Berger

o The golden triangle

o Transaction Publishers, New Brunswick (2008)

12

o Brida et al., 2011

o J.G. Brida, L. Osti, M. Faccioli

o Residents' perception and attitudes towards tourism impacts: A case study of the small rural community of Folgaria (Trentino Italy) 
o Benchmarking: An International Journal, 18 (3) (2011), pp. 359-385

13.

o Britton, 1989

o S. Britton

o Tourism, dependency and development

o T.V. Singh, H.L.. Theuns, F. Go (Eds.), Towards appropriate tourism: The case of developing countries, Peter Lang, Frankfurt (1989), pp. 93116

14.

- Brougham and Butler, 1981

o J.E. Brougham, R.W. Butler

o A segmentation analysis of resident attitudes to the social impact of tourism

o Annals of Tourism Research, 8 (4) (1981), pp. 569-590

15.

- Brunt and Courtney, 1999

o P. Brunt, P. Courtney

o Host perceptions of sociocultural impacts

o Annals of Tourism Research, 26 (3) (1999), pp. 493-515

16.

o Butler, 1980

o R.W. Butler

o The concept of a tourist area cycle of evolution: implications for management of resources 
o Canadian Geographer, 24 (1980), pp. 5-12

17.

o Byrd et al., 2009

o E. Byrd, H. Bosley, M. Dronberger

o Comparisons of stakeholder perceptions of tourism impacts in rural eastern North Carolina

o Tourism Management, 30 (5) (2009), pp. 693-703

18.

o Carmichael, 2000

o B. Carmichael

- A matrix model for resident attitudes and behaviours in a rapidly changing tourist area

o Tourism Management, 21 (6) (2000), pp. 601-611

19.

o Connell, 2005

o J. Connell

o 'What's the story in Balamory?': The impacts of a children's TV programme on small tourism enterprises on the Isle of Mull, Scotland

o Journal of Sustainable Tourism, 13 (3) (2005), pp. 228-255

20.

o Cooke, 1982

o K. Cooke

o Guidelines for socially appropriate tourism development in British Columbia

o Journal of Travel Research, 21 (1) (1982), pp. 22-28 
- Corsane and Bowers, 2012

o G. Corsane, J. Bowers

o Sense of place in sustainable tourism: A case study of the rainforest and savannahs in Guyana

o I. Convery, G. Corsane, P. Davis (Eds.), Making sense of place: Multidisciplinary perspectives, Boydell Press, Woodbridge (2012), pp. 249260

2.

o Crang, 2004

o M. Crang

o Cultural geographies of tourism

o M. Hall, A. Williams, A. Lew (Eds.), A companion to tourism: Companions to geography, Blackwell, Oxford (2004), pp. 74-84

3.

o Crouch et al., 2001

o D. Crouch, L. Aronsson, L. Wahlstrom

o Tourist encounters

o Tourist Studies, 1 (3) (2001), pp. 253-270

4.

- Davis and Morais, 2004

o J. Davis, D. Morais

o Factions and enclaves: Small towns and socially unsustainable tourism development

o Journal of Travel Research, 43 (1) (2004), pp. 3-10

5. 
o Deery et al., 2012

o M. Deery, L. Jago, L. Fredline

o Rethinking social impacts of tourism research: A new research agenda

o Tourism Management, 33 (1) (2012), pp. 64-73

6.

- Diedrich and Garcia-Buades, 2009

- A. Diedrich, E. Garcia-Buades

o Local perceptions of tourism as indicators of destination decline

o Tourism Management, 30 (4) (2009), pp. 512-521

7.

o Doxey, 1975

o Doxey, G. V. (1975). A causation theory of visitor-resident irritants, methodology and research inferences. In Conference Proceedings: Sixth Annual Conference of Travel Research Association, San Diego, pp. 195-198.

8.

o Dredge, 1999

o D. Dredge

o Destination place and planning

o Annals of Tourism Research, 26 (4) (1999), pp. 772-779

9.

O Easterling, 2004

o D.S. Easterling 
o The residents' perspective in tourism research: A review and synthesis

o Journal of Travel \& Tourism Marketing, 17 (4) (2004), pp. 45-62

10.

o Easterling, 2005

o D. Easterling

o Residents and tourism: What's really at stake

o Journal of Travel and Tourism Marketing, 18 (4) (2005), pp. 49-64

11.

o Echtner, 1999

o C. Echtner

o The semiotic paradigm: Implications for tourism research

o Tourism Management, 20 (1) (1999), pp. 47-57

12

o Evans, 1976

o N. Evans

o Tourism and cross cultural communication

o Annals of Tourism Research, 3 (4) (1976), pp. 189-198

13

O Freitag, 1994

o T.G. Freitag

o Enclave tourism development: For whom the benefits roll?

o Annals of Tourism Research, 21 (3) (1994), pp. 538-554 
14.

o Gilbert and Clark, 1997

o D. Gilbert, M. Clark

o An exploratory examination of urban tourism impact, with reference to residents attitudes, in the cities of Canterbury and Guildford

o $\quad$ Cities, 14 (6) (1997), pp. 343-352

15.

o Gilchrist, 2004

- A. Gilchrist

o The well-connected community: A networking approach to community development

o The Policy Press, Bristol (2004)

16.

- Gramann and Burdge, 1981

o J.H. Gramann, R.J. Burdge

o The effects of recreation goals on conflict resolution: The case of waterskiers and fishermen

o Journal of Leisure Research, 13 (1) (1981), pp. 15-27

17.

o Green, 2005

o R. Green

o Community perceptions of environmental and social change and tourism development on the island of Koh Samui, Thailand

o Journal of Environmental Psychology, 25 (1) (2005), pp. 37-56

18. 
o Greenwood, 1972

o D. Greenwood

o Tourism as an agent of change: A Spanish basque case

o Ethnology, 11 (1) (1972), pp. 80-91

19.

o Greider et al., 1991

o T. Greider, R. Krannich, H. Berry

o Local identity, solidarity, and trust in changing rural communities

o Sociological Focus, 24 (4) (1991), pp. 263-282

20.

o Gretzel and Kennedy-Eden, 2012

o U. Gretzel, H. Kennedy-Eden

o Meta-analysis of tourism research

o L. Dwyer, A. Gill, N. Seetarum (Eds.), Handbook of research methods in tourism: Quantitative and qualitative approaches, Edward Elgar, Cheltenham, UK (2012), pp. 459-471

1.

o Gu and Ryan, 2012

o H. Gu, C. Ryan

o Tourism destination evolution: A comparative study of Shi Cha Hai Beijing Hutong businesses' and residents' attitudes

o Journal of Sustainable Tourism, 20 (1) (2012), pp. 23-40 
o Gustafson, 2006

o P. Gustafson

o Place attachment and mobility

- M. McIntyre, D. Williams, K. McHugh (Eds.), Multiple dwelling and tourism: Negotiating place, home and identity, CABI, Oxfordshire, UK (2006), pp. 17-31

3.

- Haralambopoulos and Pizam, 1996

o N. Haralambopoulos, A. Pizam

o Perceived impacts of tourism: The case of Samos

o Annals of Tourism Research, 23 (3) (1996), pp. 503-526

4.

o $\quad$ Hayllar et al., 2008

o B. Hayllar, T. Griffin, D. Edwards

o Urban tourism precincts: Engaging with the field

o B. Hayllar, T. Griffin, D. Edwards (Eds.), City spaces - tourist places: Urban tourism precincts, Routledge, Sydney (2008), pp. 1-19

5.

o Hernandez and Cohen, 1996

o S.A. Hernandez, J. Cohen

o Residents' attitudes towards an instant resort enclave

o Annals of Tourism Research, 23 (4) (1996), pp. 755-779

6.

o Horn and Simmons, 2002 
o C. Horn, D. Simmons

o Community adaptation to tourism: Comparisons between Rotorua and Kaikoura, New Zealand

o Tourism Management, 23 (2) (2002), pp. 133-143

7.

o $\mathrm{Hsu}, 2000$

o C.H.C. Hsu

o Residents' support for legalized gaming and perceived impacts of riverboat casinos: Changes in five years

o Journal of Travel Research, 38 (4) (2000), pp. 390-395

8.

o $\quad$ Hudman, 1978

o L. Hudman

o Tourist impacts: The need for regional planning

o Annals of Tourism Research, 5 (1) (1978), pp. 112-125

9.

o Jago et al., 2006

o L. Jago, M. Deery, L. Fredline

o Tourism in a small community: Risks and benefits

o Tourism Review International, 10 (1-2) (2006), pp. 91-101

10.

o Johnson and Snepenger, 1994

o J.D. Johnson, D.J. Snepenger

o Resident's perceptions of tourism development 
o Annals of Tourism Research, 21 (3) (1994), pp. 629-642

11.

O Jorgensen and Stedman, 2001

o B.S. Jorgensen, R.C. Stedman

o Sense of place as an attitude: Lakeshore owners attitudes toward their properties

o Journal of Environmental Psychology, 21 (3) (2001), pp. 233-248

12.

o Jurowksi et al., 1997

o C. Jurowksi, M. Uysal, D.R. Williams

o A theoretical analysis of host community resident reactions to tourism

o Journal of Travel Research, 36 (2) (1997), pp. 3-11

13.

o Keogh, 1990

o B. Keogh

o Public participation in community tourism planning

o Annals of Tourism Research, 17 (3) (1990), pp. 449-465

14.

o Kianicka et al., 2006

o S. Kianicka, M. Buchecker, M. Hunziker, U. Müller-Böker

o Locals' and tourists' sense of place: A case study of a Swiss alpine village

o Mountain Research and Development, 26 (1) (2006), pp. 55-63 
15.

- $\quad$ King et al., 1993

- B. King, A. Pizam, A. Milman

o Social impacts of tourism: Host perceptions

o Annals of Tourism Research, 20 (4) (1993), pp. 650-665

16.

- Korça, 1998

- P. Korça

o Resident perceptions of tourism in a resort town

o Leisure Sciences, 20 (3) (1998), pp. 193-212

17.

o La Flamme, 1979

- A. La Flamme

o The impact of tourism: A case from the Bahamas Island

o Annals of Tourism Research, 6 (2) (1979), pp. 137-148

18.

o Lankford, 1994

o S.V. Lankford

o Attitudes and perceptions toward tourism and rural regional development

o Journal of Travel Research, 32 (3) (1994), pp. 35-43

19.

o Látková and Vogt, 2011 
- P. Látková, C.A. Vogt

o Attitudes toward existing and future tourism development in rural communities

o Journal of Travel Research, 51 (1) (2011), pp. 50-67

20.

o Lepp, 2007

o A. Lepp

o Residents' attitudes towards tourism in Bigodi village, Uganda

o Tourism Management, 28 (3) (2007), pp. 876-885

1.

o Lew and McKercher, 2006

o A. Lew, B. McKercher

o Modeling tourist movement: A local destination analysis

o Annals of Tourism Research, 33 (2) (2006), pp. 403-423

2.

o $\quad$ Liu et al., 1987

o J.C. Liu, P.J. Sheldon, T. Var

o Resident perception of the environmental impacts of tourism

o Annals of Tourism Research, 14 (1) (1987), pp. 17-37

3.

- Liu and Var, 1986

o J.C. Liu, T. Var

o Resident attitudes toward tourism impacts in Hawaii 
o Annals of Tourism Research, 13 (2) (1986), pp. 193-214

4.

o Low and Altman, 1992

o S. Low, I. Altman

o Place attachment: A conceptual inquiry

o I. Altman, S.M. Low (Eds.), Place attachment, Plenum Press, New York (1992), pp. 1-12

5.

o Mahon, 2007

o M. Mahon

0 The changing faces of rural populations

o Journal of Rural Studies, 23 (3) (2007), pp. 345-356

6.

- McCabe and Stokoe, 2004

o S. McCabe, E.H. Stokoe

o Place and identity in tourist accounts

o Annals of Tourism Research, 31 (3) (2004), pp. 601-622

7.

o McKercher et al., 2008

o B. McKercher, H. du Cros, K. Weber

o Rationalizing inappropriate behaviour

o Journal of Sustainable Tourism, 16 (4) (2008), pp. 369-385

8. 
o $\quad$ Montgomery, 1998

o J. Montgomery

o Making a city: Urbanity, vitality and urban design

o Journal of Urban Design, 3 (1) (1998), pp. 93-116

9.

- Mordue, 2001

o T. Mordue

o Performing and directing resident/tourist cultures in Heartbeat country

o $\quad$ Tourist Studies, 1 (3) (2001), pp. 233-252

10.

O Nelson, 2001

o P. Nelson

o Rural restructuring in the American West: Land use, family and class discourses

o Journal of Rural Studies, 17 (4) (2001), pp. 395-407

11.

o Nunkoo and Ramkissoon, 2010

o R. Nunkoo, H. Ramkissoon

o Small island urban tourism: A residents' perspective

o Current Issues in Tourism, 13 (1) (2010), pp. 37-60

12.

o Nunkoo et al., 2013

o R. Nunkoo, S.L.J. Smith, H. Ramkissoon 
o Residents' attitudes to tourism: A longitudinal study of 140 articles from 1984 to 2010

o Journal of Sustainable Tourism, 21 (1) (2013), pp. 5-25

13.

O Park and Stokowski, 2009

o M. Park, P. Stokowski

o Social disruption theory and crime in rural communities: Comparisons across three levels of tourism growth

o Tourism Management, 30 (6) (2009), pp. 905-915

14.

o Perez and Nadal, 2005

o E. Perez, J. Nadal

o Host community perceptions a cluster analysis

o Annals of Tourism Research, 32 (4) (2005), pp. 925-941

15.

o Pizam, 1978

o A. Pizam

o Tourism's impacts: The social costs to the destination community as perceived by its residents

o Journal of Travel Research, 16 (4) (1978), pp. 8-12

16

o Pizam, 1994

o A. Pizam

o Planning a tourism research investigation 
o J. Ritchie, C. Goeldner (Eds.), Travel, tourism and hospitality research: A handbook for managers and researchers, John Wiley and Sons, Toronto (1994), pp. 91-114

17.

O Prentice, 1993

o R.C. Prentice

o Community driven tourism planning and residents' preferences

o Tourism Management, 14 (12) (1993), pp. 218-227

18.

- Proshansky, 1978

o H.M. Proshansky

o The city and self-identity

o Environment and Behavior, 10 (2) (1978), pp. 147-169

19.

o $\quad$ Purdue et al., 1999

o R. Purdue, P. Long, Y. Kang

o Boomtown tourism and resident quality of life: The marketing of gaming to host community residents

o Journal of Business Research, 44 (3) (1999), pp. 165-167

20.

O $\quad$ Reed, 1997

o M.G. Reed 
o Power relations and community based tourism planning

o Annals of Tourism Research, 24 (13) (1997), pp. 556-591

1.

- Ross, 1992

o G.F. Ross

o Resident perceptions of the impact of tourism on an Australian city

o Journal of Travel Research, 30 (3) (1992), pp. 13-17

2.

o Russell and Faulkner, 1999

o R. Russell, B. Faulkner

o Movers and shakers: Chaos makers in tourism development

o Tourism Management, 20 (4) (1999), pp. 411-423

3.

o $\quad$ Ryan and Montgomery, 1994

o C. Ryan, D. Montgomery

o The attitudes of Bakewell residents to tourism and issues in community responsive tourism

o Tourism Management, 15 (5) (1994), pp. 358-369

4.

o $\quad$ Ryan et al., 1998

o C. Ryan, A. Scotland, D. Montgomery 
o Resident attitudes to tourism development-A comparative study between the Rangitikei, New Zealand and Bakewell, United Kingdom

o International Journal of Tourism Research, 4 (2) (1998), pp. 115-130

5.

o Saunders et al., 2000

o M. Saunders, P. Lewis, A. Thornhill

o Research methods for business students

o FT Prentice Hall, Harlow, UK (2000)

6.

o Shamai and Ilatov, 2005

o S. Shamai, Z. Ilatov

o Measuring sense of place: Methodological aspects

o Tijdschrift voor Economische en Social Geografie, 96 (5) (2005), pp. 467-476

7.

o Shaw and Williams, 2004

o G. Shaw, A.M. Williams

o Tourism and tourism spaces

o Sage, London (2004)

8.

o Sheldon and Var, 1984

o P. Sheldon, T. Var 


\section{o Resident attitudes to tourism in North Wales}

o Tourism Management, 5 (1) (1984), pp. 40-47

9.

o $\quad$ Snaith and Haley, 1999

o T. Snaith, A. Haley

o Residents' opinions of tourism development in the historic city of York, England

o Tourism Management, 20 (5) (1999), pp. 595-603

10.

o Snepenger et al., 2003

o D. Snepenger, L. Murphy, R. O'Connell, E. Gregg

o Tourist and residents use of a shopping space

o Annals of Tourism Research, 30 (3) (2003), pp. 567-580

11.

o Soontayatron, 2014

o S. Soontayatron

o Thais' coping with sociocultural impacts of tourism development

o Asia Pacific Journal of Tourism Research, 19 (10) (2014), pp. 1228-1238

12

o Stephenson and Ali-Knight, 2010

o M.L. Stephenson, J. Ali-Knight

o Dubai's tourism industry and its societal impact: Social implications and sustainable challenges

o Journal of Tourism and Cultural Change, 8 (4) (2010), pp. 278-292 
13.

o Stewart et al., 1998

o E.J. Stewart, B.M. Hayward, P.J. Devlin, D. Kirby

o The "place" of interpretation: A new approach to the evaluation of interpretation

o Tourism Management, 19 (3) (1998), pp. 257-266

14.

o Stokoe and Shumaker, 1981

o D. Stokoe, S.A. Shumaker

o People in places: a transactional view of settings

o J. Harvey (Ed.), Cognition, social behavior and the environment, Lawrence Erlbaum Associates, Hillsdale (1981), pp. 441-488

15.

o Stonich, 1998

o S. Stonich

o Political ecology of tourism

o Annals of Tourism Research, 25 (1) (1998), pp. 25-54

16.

o Stynes and Stewart, 1993

o D.J. Stynes, S.I. Stewart

o Tourism development and recreation: Some findings from a case study

o Journal of Park and Recreation Administration, 11 (4) (1993), pp. 30-44

17.

o Tapsell and Tunstall, 2008 
o S. Tapsell, S. Tunstall

o "I wish l'd never heard of Banbury": The relationship between 'place' and the health impacts from flooding

o Health \& Place, 14 (2) (2008), pp. 133-154

18.

o Tatoglu et al., 2002

o E. Tatoglu, F. Erdal, H. Ozgur, S. Azakli

o Resident attitudes toward tourism impacts: The case of Kusadasi in Turkey

o International Journal of Hospitality \& Tourism Administration, 3 (3) (2002), pp. 79-100

19.

o $\underline{\text { Teo, } 1994}$

o P. Teo

o Assessing socio-cultural impacts: The case of Singapore

o Tourism Management, 15 (2) (1994), pp. 126-136

20.

o $\quad$ Teye et al., 2002

o V. Teye, S.F. Sonmez, E. Sirakaya

o Residents' attitudes toward tourism development

o Annals of Tourism Research, 29 (3) (2002), pp. 668-688 